\title{
Pre-Carboniferous Structural History of S.E. Cape Breton Island, Nova Scotia*
}

HERWART HELMSTAEDT and SUBHAS TELLA

Department of Geological Sciences, McGill University, Montreal, Quebec

\section{Introduction}

This paper deals with the tectonic development of southeastern Cape Breton Island from the Hadrynian to the beginning of the Carboniferous. The area is part of the Avalonian platform (Poole, 1967) or Avalon belt (Rodgers, 1972) stretching along the southeastern margin of the northern Appalachians from the Avalon Peninsula of southeastern Newfoundland to southeastern Cape Breton Island, southern New Brunswick, and eastern Massachusetts. Segments of this belt are characterized by Late Precambrian (Hadrynian) volcanic and intrusive rocks overlain by Cambrian strata with an Atlantic-type trilobite fauna. The Hadrynian rocks have been affected by the Avalonian orogeny (Lilly, 1966; Hughes, 1970; Rodgers, 1972).

Interest in the tectonic history of the Avalon belt was renewed with recent plate-tectonic reconstructions of the evolution of the northern Appalachians (Wilson, 1966; Bird and Dewey, 1970; Schenk, 1971, 1972; Rodgers, 1972). The uncertainty about the role of the Avalon belt in such platetectonic models stems from disagreements regarding the nature and age of the basement to the Hadrynian volcanics, and from a still imperfect knowledge of the timing and nature of igneous, metamorphic and deformational events in some parts of the belt. In the present paper we attempt to clarify some of these uncertainties for southeastern Cape Breton Island. Four points, which we consider of particular importance to a regional tectonic synthesis of the Avalon belt, are emphasized: 1) The age of the George River Group, the basement to the Hadrynian volcanic rocks; 2) The nature of the Avalonian orogeny; 3) The tectonic environment of Avalonian magmatism as interpreted from the chemical composition of Late Hadrynian volcanic and intrusive rocks; and 4) The timing of post-Cambrian and pre-Carboniferous deformation.

Our fieldwork in southeastern Cape Breton Island was conducted under the auspices of the Geological Survey of Canada (Helmstaedt and Tella, 1972). Previous mapping in this area (Fig. 1) is by Bell and Goranson (1938), Hutchinson (1952), Weeks (1954), Kelly (1967), and Milligan (1970). Fairbairn et al (1960), Wanles et al (1968), Wanless (1969) and Cormier (1972) dated numerous samples of igneous rocks.

The stratigraphic sequence resulting from the previous, and our studies is summarized in Table 1.

TABLE 1

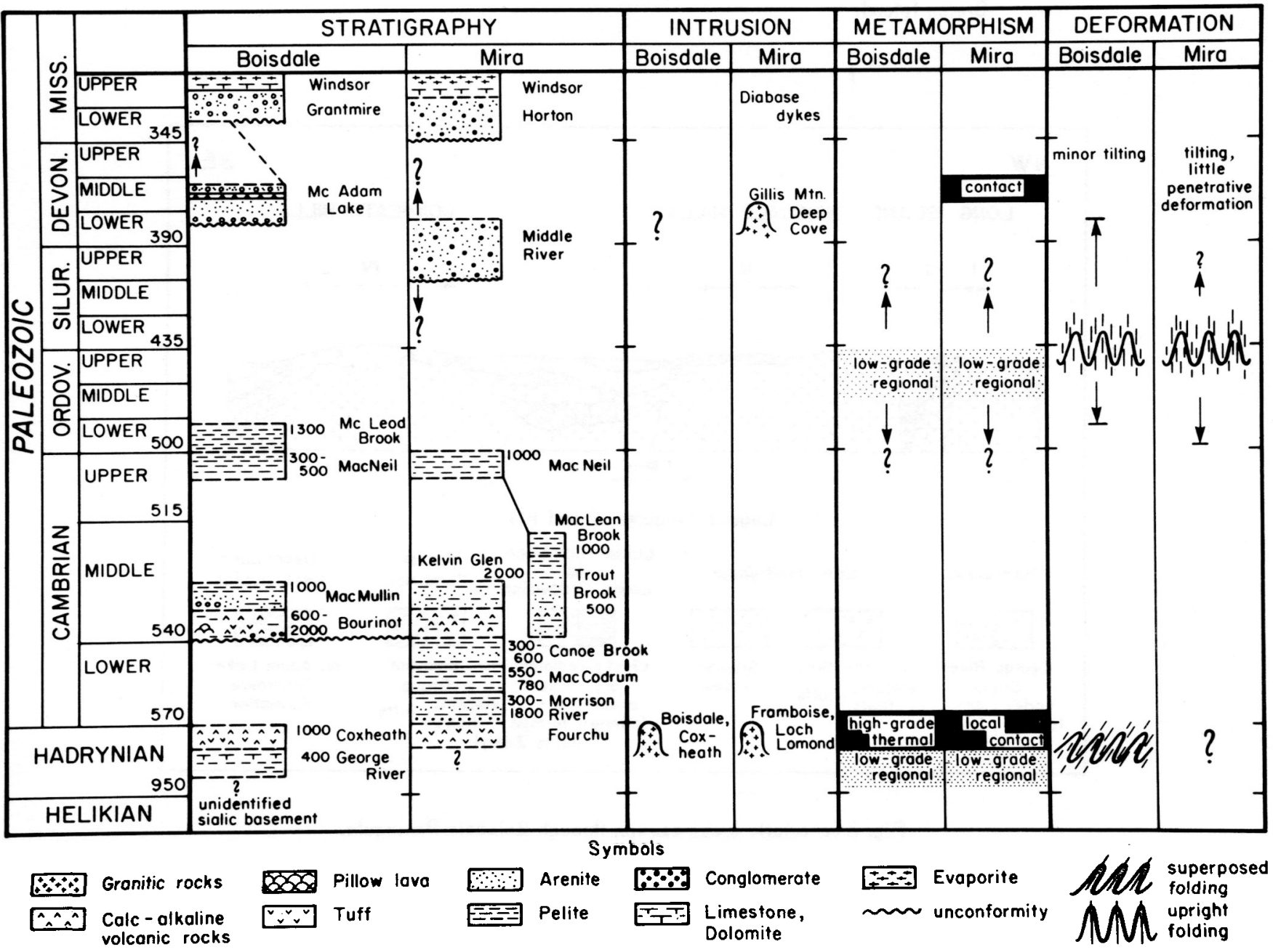

* Manmerrint romejued Tune 16. 1974. 


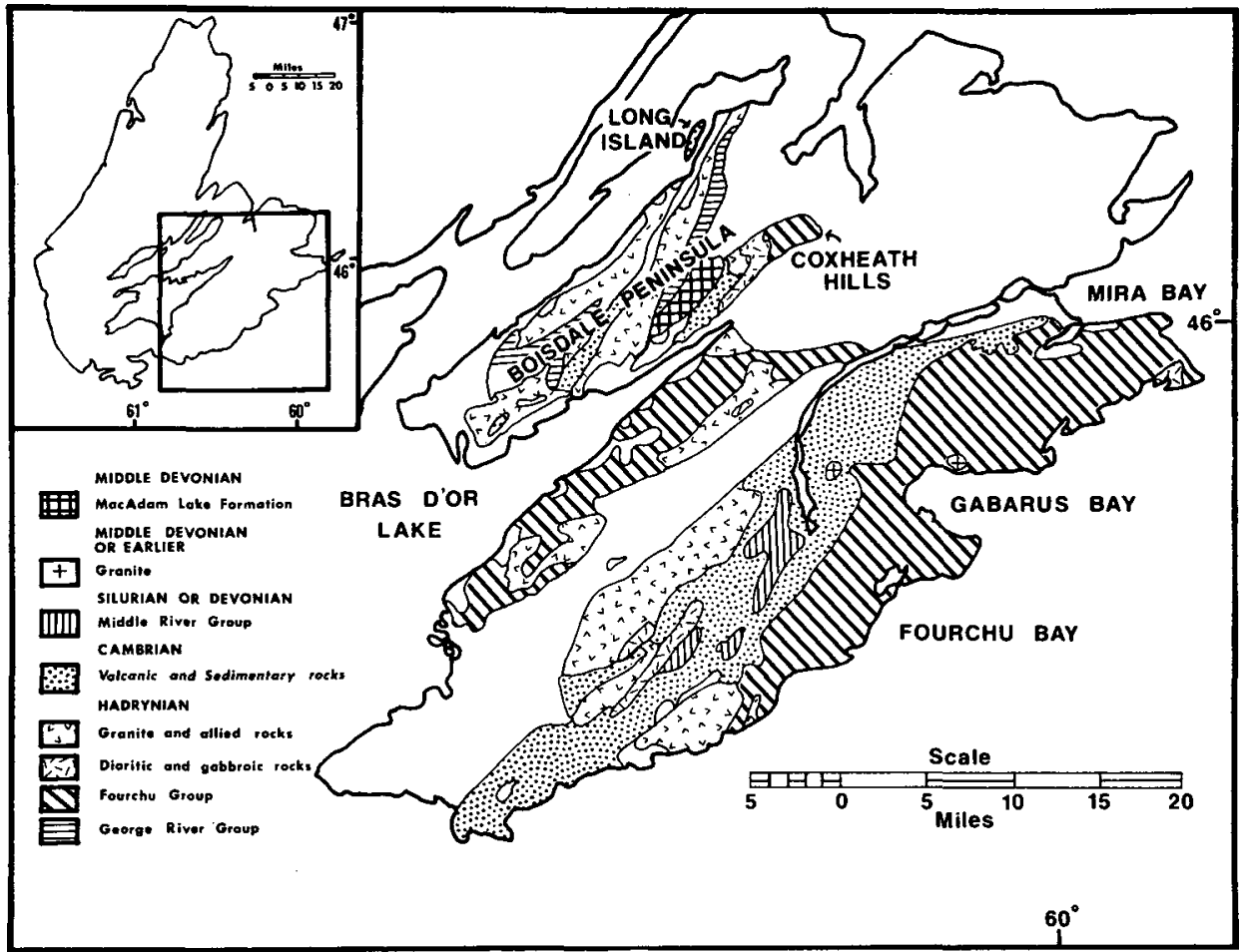

Fig. I Location map showing distribution of Pre-Carboniferous rocks in southeastern Cape Breton Is land.

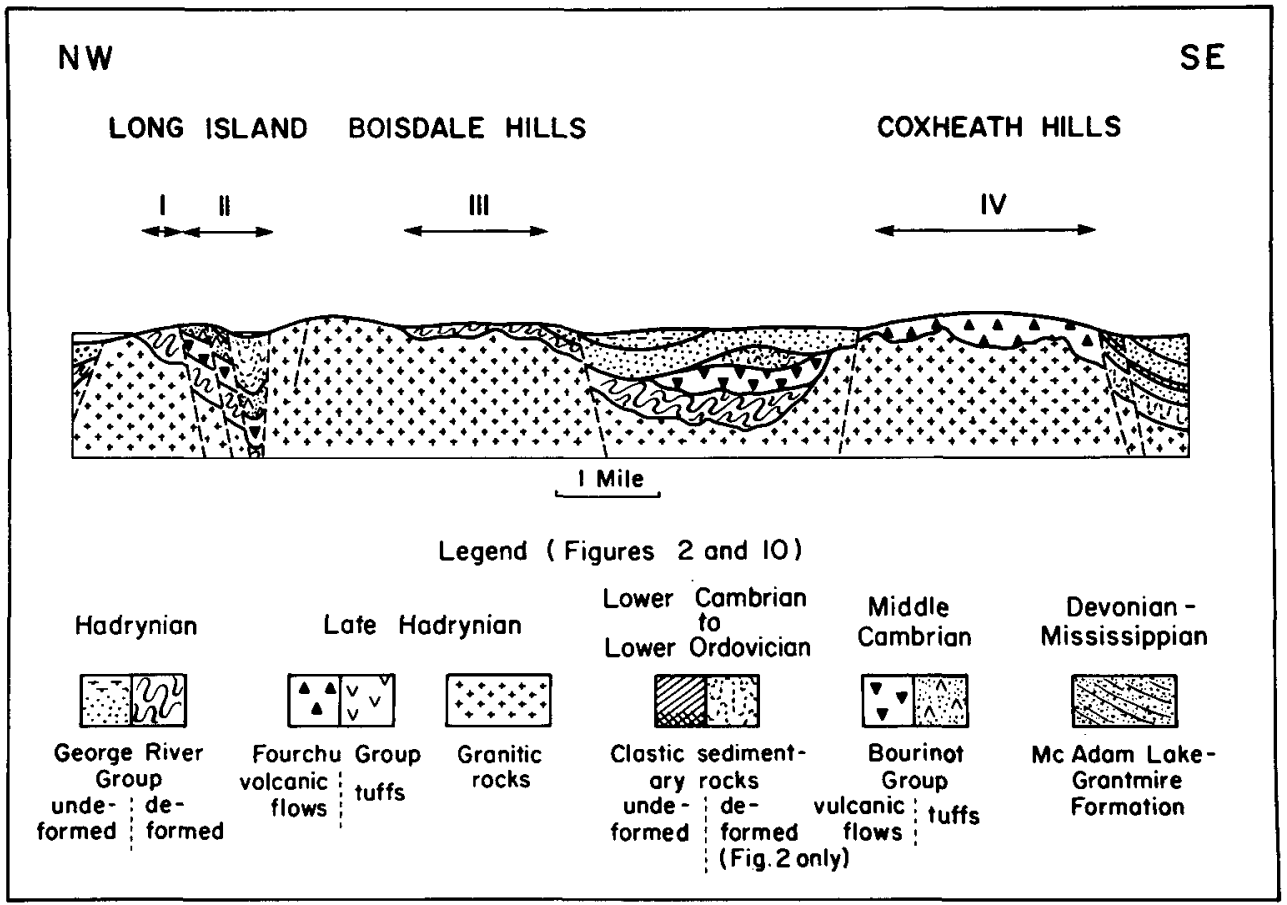

Fig. 2 Schematic cross-section through Boisdale Peninsula. 
I

George River Gr. Long Island/Ironville

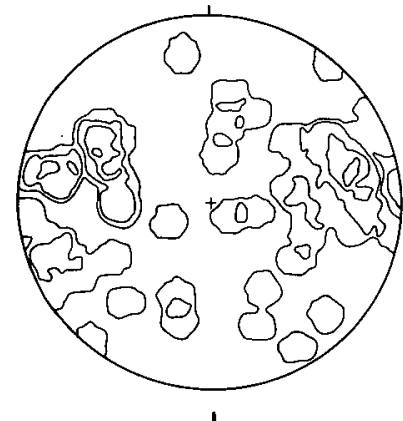

63 poles to $S_{0}$ I, 3, 6, $9 \%$

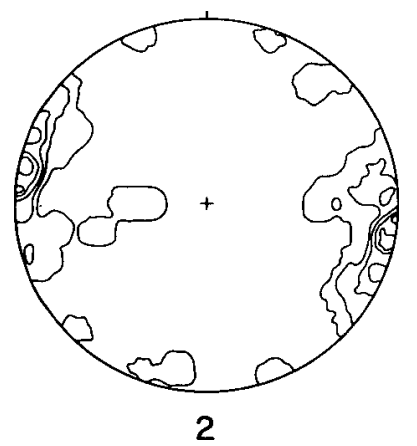

59 poles to most prominent tectonic $S$ (in places $S_{2}$ ) I, $5,10,15,20 \%$
II

Cambrian McLeod River Section

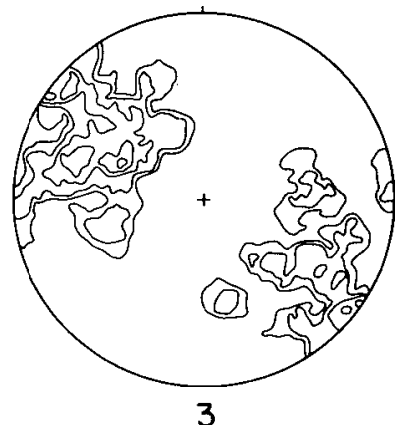

138 poles to $S_{0}$ $1,2,4,6,8 \%$

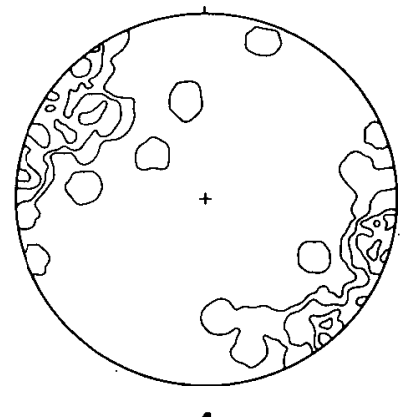

4

71 poles to $S_{1}$ $1,4,8,12 \%$
III

George River Gr. Steele Cross, Scotch Lake

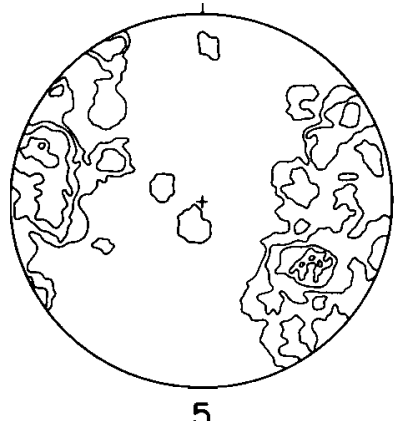

169 poles to $S_{0}$ $1,2,4,6,8 \%$

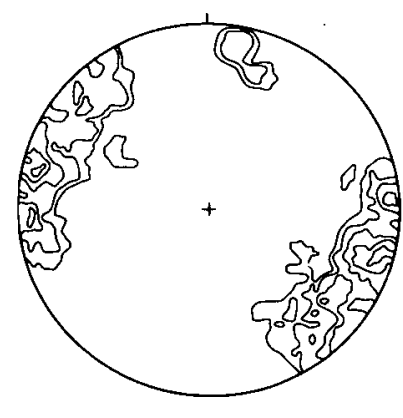

6

100 poles to (?) $S$ I, $2,4,6,8 \%$
IV

Coxheath Volcanics

Coxheath Hills

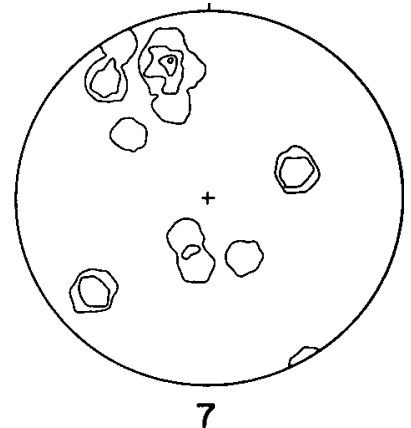

16 poles to $S_{0}$ $1,5,10,15,20 \%$

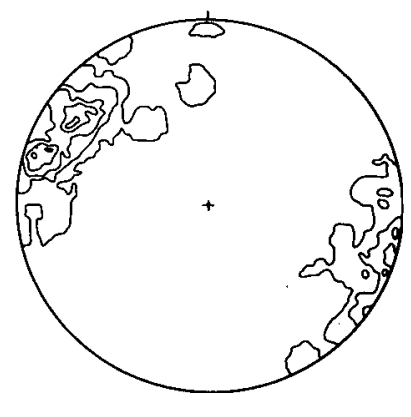

8

113 poles to $S_{1}$ $1,4,8,12,16 \%$

Fig. 3 - Planar Fabric elements in Precambrian and Cambrian rocks of Boisdale Peninsula. The Roman numerals refer to zones indicated on Figure 2. 
1) Age of the George River Group

In Cape Breton Island all unfossiliferous metasedimentary rocks containing crystalline limestone have been referred to as George River Group (for a review see Kelley, 1967 and Milligan, 1970). It is therefore quite likely that this group contains rocks of differing ages. Remarks made here for the southeastern part of Cape Breton Island may thus not apply to the northern part of the island (see, for instance, wiebe, 1972). As a whole the George River Group is commonly correlated with the Green Head Group of southern New Brunswick (Weeks, 1954; Poole et al, 1970), and because both groups include crystalline limestones, a parallel with the Grenville Group of the southeastern Canadian Shield is often drawn (Schenk, 1971; Wiebe, 1972). However, Poole (1967) and Rodgers (1972) pointed out that these rocks may in fact be younger than the Grenville Group.

In the Boisdale area rocks of the George River Group have been intruded by Hadrynian granitoid rocks, and pebbles of contact metamorphosed George River rocks occur in Middle Cambrian conglomerates. A contact of the George River Group with the Late Hadrynian Fourchu and Coxheath volcanics is not exposed, but it was generally assumed that the George River Group predates the volcanic rocks. The question is, by how much time?

Our field studies suggest that the Late Hadrynian volcanics and the George River Group are not greatly separated in time. A George River limestone breccia on the west coast of Long Island in the St. Andrew Channel of the Bras d'Or Lake contains volcanic fragments which resemble andesites from the Coxheath volcanics approximately 6 miles to the southeast (Fig. 1). This relationship implies that Coxheath volcanism began during the late stage of the George River sedimentation, and that the two formations are conformable. A correlation of the George River Group with the Grenville Grouo is therefore untenable. A nearby sialic source of possible pre-Hadrynian age is required to yield the quartz sands in the George River Group (Fig. 10).

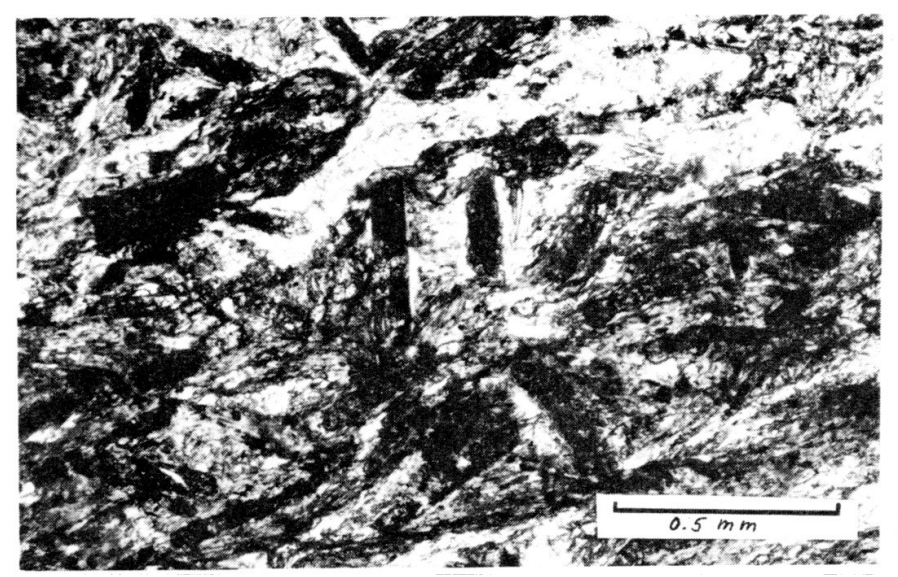

Fig. 4. Photomicrograph of deformed chloritoid in metapelite of George River Group near Ironville.
2) The Nature of the Avalonian Orogeny

From the work of Hutchinson (1952) and weeks (1954) it is evident that Hadrynian and Cambrian strata are conformable in the Mira valley, whereas only a few miles to the northwest, on the Boisdale peninsula, Lower Cambrian strata are missing and Middle Cambrian strata rest directly on Hadrynian volcanics (Table 1). Therefore, the Boisdale Peninsula, on which the George River Group, Fourchu volcanics (= Coxheath volcanics), Late Hadrynian intrusions, and Middle Cambrian strata occur in close geographic proximity, is the only area in Cape Breton Island where Hadrynian to Early Cambria deformational structures can be distinguished with some certainty from post-Cambrian structures. Unfortunately, the Boisdale peninsula is cut by northeasterly striking faults and correlation of fabric elements from one fault block to another is quite difficult.

Both the George River Group and the Cambrian strata of the Boisdale Peninsula have been deformed into moderate to tight upright folds with northeasterly striking axial planes (Fig. 2). Because both rock units are nowhere in stratigraphic contact, but only in fault contacts, it is difficul to establish on the basis of the number, orientatio and character of fabric elements whether or not the were deformed together (Fig. 3). However, the sequence of metamorphism and deformation of the George River Group can be recognized near Ironville and on Long Island, where it is possible to distinguish regional metamorphic effects in George River pelites from the effects of thermal metamorphism du to the Late Hadrynian intrusions. Pelitic rocks southwest of Ironville are chloritoid-bearing, the chloritoid being deformed by a regionally developed planar fabric (Fig. 4) which in places can be identified as the second tectonic fabric of the George River rocks. This second fabric has been overgrown by postkinematic chiastolitic andalusite which can clearly be related to the contact metamorphism of the Late Hadrynian intrusions (Fig. 5). The stratigraphic proof that all these effects are at least pre-Middle Cambrian comes from the fact that pebbles of contact metamorphosed George River

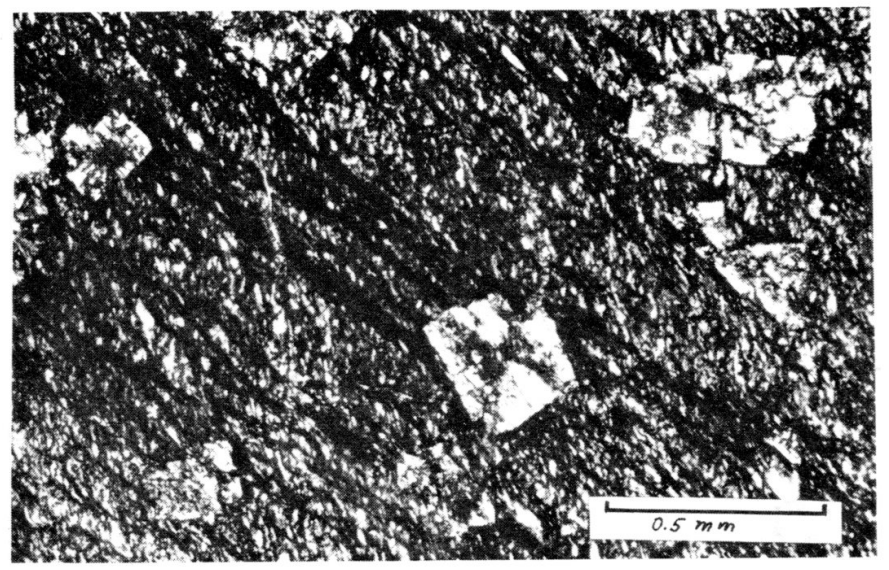

Fig. 5. Photomicrograph of andalusite overgrowing crenulotion cleovage (S2) in metapelite of George River Group near Ironville. 

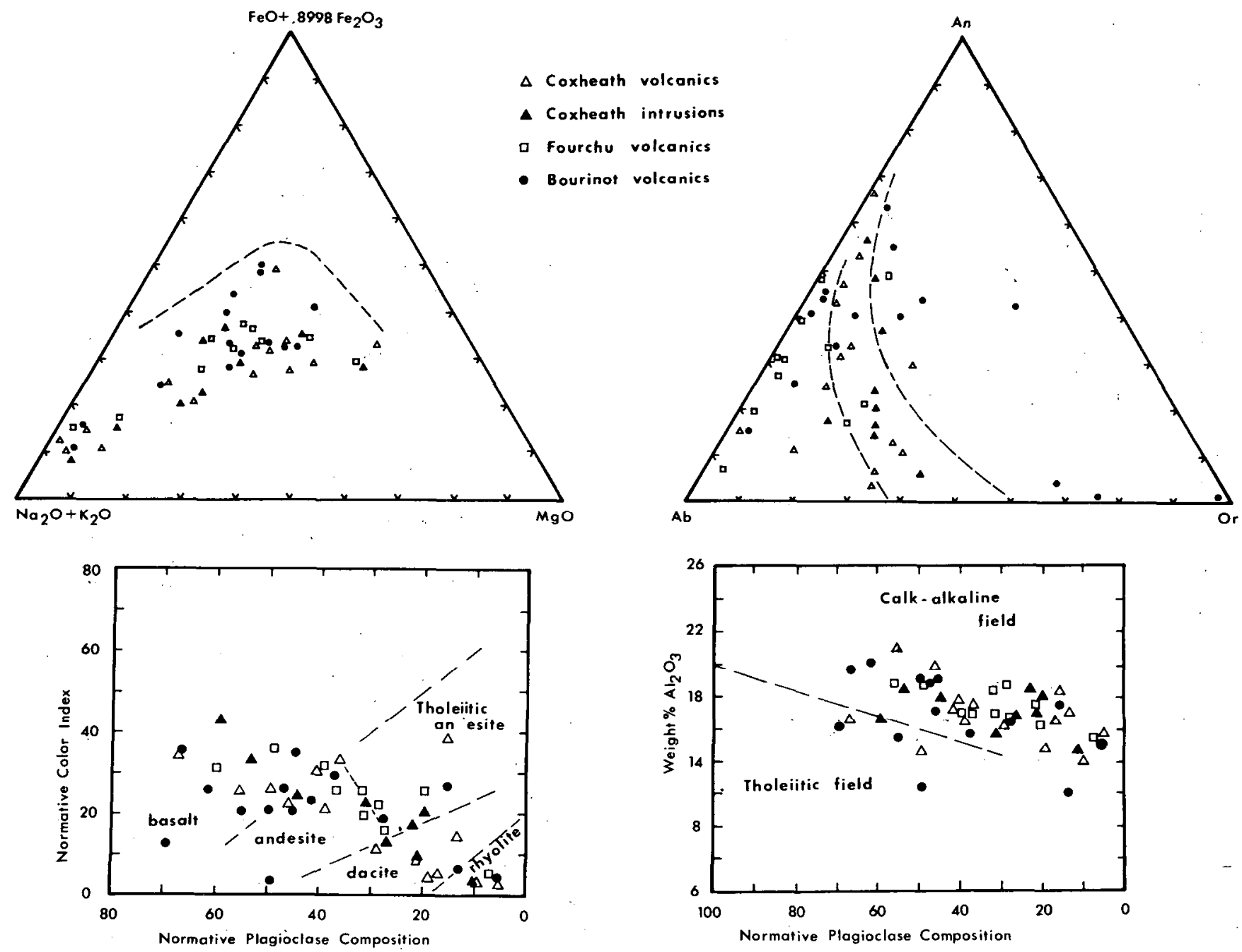

Fig. 6. AFM diagram, normative feldspar plot, and plots of normative plagioclase composition against A1203 and color index of Fourchu volcanics, Coxheath volcanic and intrusive rocks, and bourinot volcanics.

pelites and intrusive rocks have been found in the Middle Cambrian conglomerates of the Bourinot Group on Long Island.

Weeks (1954) suggested a Precambrian deformational event in this region, but he assumed that the granitoid intrusions were of Lower to Middle

Devonian age. Bell and Goxanson (1938) on the other hand, recognized that most of these intrusions in the Boisdale area are older than the Cambrian. The latter interpretation has now been confirmed by $\mathrm{Rb}-$ Sr age determinations (Cormier, 1972).

The Avalonian orogeny in southeastern Cape Breton Island is thus documented by penetrative deformation and low-grade regional metamorphism of the Hadrynian George River Group, volcanism and plutonism, as well as related thermal metamorphism. The thermal metamorphism related to the Late Hadrynian intrusions lead to locally intense metamorphic recrystallization (see also Milligan, 1970). It should, however, be emphasized that the highlevel emplacement of the granitic rocks caused little deformation in the country rocks, and the conclusion of Williams et al. (1972) that intense metamorphic recrystallization of the George River Group is an indication for intense deformation is not justified in the Boisdale Peninsula. Metamorphic assemblages resulting from the thermal event are typical of high temperature-low pressure metamorphism (see also Milligan, 1970).

3) Chemical Composition of Igneous Rocks as Indicator of the Tectonic Environment

Two igneous episodes have been distinguished in the Late Hadrynian-Cambrian sequence of southeastern Cape Breton Island:

a) Late Hadrynian volcanic activity is indicated by the Fourchu Group of southeastern Cape Breton IsIand and the Coxheath volcanics of the Boisdale Peninsula. At the latter locality the volcanic sequence is intruded by granitic rocks ranging from diorite to granodiorite, monzonite, and granite. Absolute age determinations of these intrusive rocks have been conducted by Cormier (1972) who also summarizes the results of earlier studies. Most dates are Late Hadrynian to Early Cambrian, a result consistent with the fact that pebbles of granodiorite, 

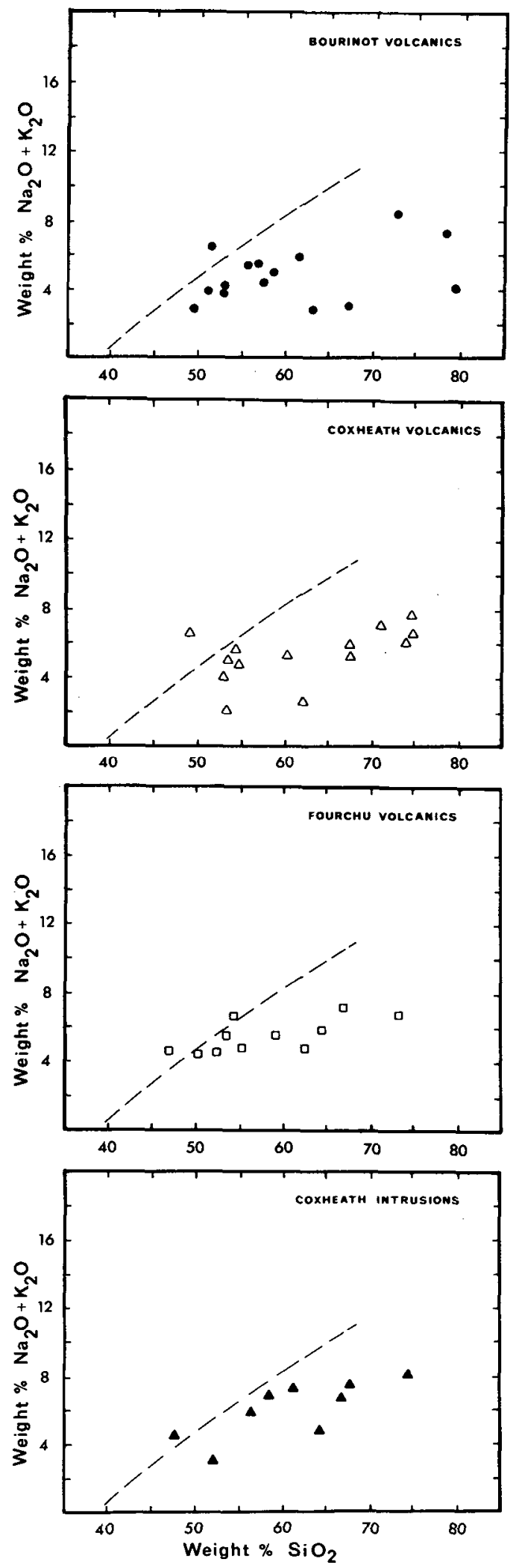

Fig. 7. Plots of total alkali content against $\mathrm{SiO} 2$ of Fourchu volcanics, Coxheath volcanic and intrusive rocks and Bourinot volcanics. monzonite and granite occur in conglomerates of the Middle Cambrian Bourinot Group.

b) Cambrian volcanic activity is confined to the Middle Cambrian Bourinot Group. On the Boisdale Peninsula volcanic rocks are interlayered with fossiliferous Middle Cambrian strata including conglomerates (Hutchinson, 1952). As the correlation of the volcanic rocks of the Stirling area in southeastern Cape Breton Island to the Middle Cambrian Bourinot Group (Weeks, 1954) is not based on fossil evidence, the Middle Cambrian age of these volcanics is somewhat uncertain (Hutchinson, oral communication, 1973).

Representative suites of Fourchu volcanics, Coxheath volcanics, Coxheath intrusions and Bourinot volcanics have been analyzed chemically in the chemistry laboratory of the Geological Survey of Canada in order to test the correlation between Fourchu and Coxheath volcanics, to suggest genetic relationships between Coxheath volcanics and intrusives, and to detect possible chemical differences between the Late Hadrynian and Middle Cambrian volcanics. The complete analyses of 49 samples will be presented in another publication (Helmstaedt and Tella, in preparation). In this paper we discuss possible tectonic conclusions based on the chemical characteristics of these rocks.

Figures 6 and 7 show plots of the total alkali content against weight $\& \mathrm{SiO}_{2}$, A F M diagrams, plots of normative plagioclase compositions against colour index and $\mathrm{Al}_{2} \mathrm{O}_{3}$, and normative feldspar plots. These parameters are used by Irvine and Baragar (1971) for a chemical classification of common volcanic rocks. If it is assumed that the analyses represent the primary igneous compositions, the figures indicate that all four rock groups have clear affinities to calcalkaline suites. We also prepared plots of the alkali-lime index according to Peacock (1931) (Fig. 8) in order to compare the Cape Breton suites with similar plots of volcanic rocks from the Avalon Peninsula (Papezik, 1970). From these figures the calc-alkaline character of the Cape Breton suites is also evident.

Increasing use has been made recently of chemical compositions in interpreting the tectonic environment of igneous rocks (e.g. Lipman, 1970; Hughes, 1970; Papezik, 1970). Martin and Piwinskii (1972) have reviewed the basis for such interpretations using the chemical compositions of recent volcanic rocks. They provided clear evidence that calc-alkaline rock suites are restricted to island arcs and Andean-type continental margins which are considered as "orogenic" environments or areas of regional compression. Alkaline rock suites which are normally bimodel are characteristic of "non-orogenic" environments or areas of regional extension. The calc-alkaline rock suites of southeastern Cape Breton Island in which intermediate compositions predominate would therefore indicate a compressional environment for the Late Precambrian and the Middle Cambrian.

Whereas the calc-alkaline affinity of the Late Hadrynian and Cambrian suites of southeastern 

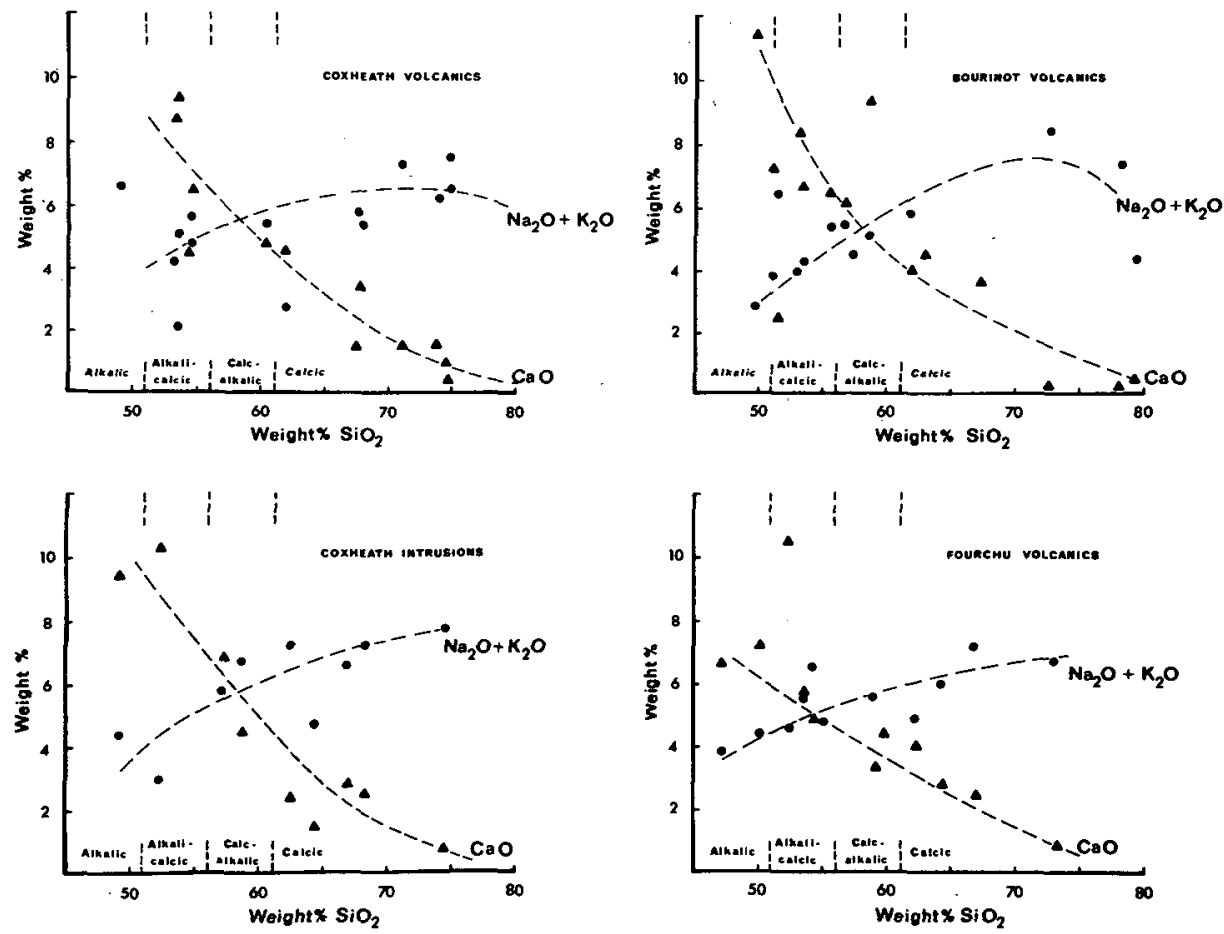

Fig. 8. Alkali-lime index according to Peacock (1931) of Fourchu volcanics, Coxheath volcanic and intrusive rocks and Bourinot Volcanics. Circles $\mathrm{Na} 20$ plus K2O, Triangles $\mathrm{CaO}$.

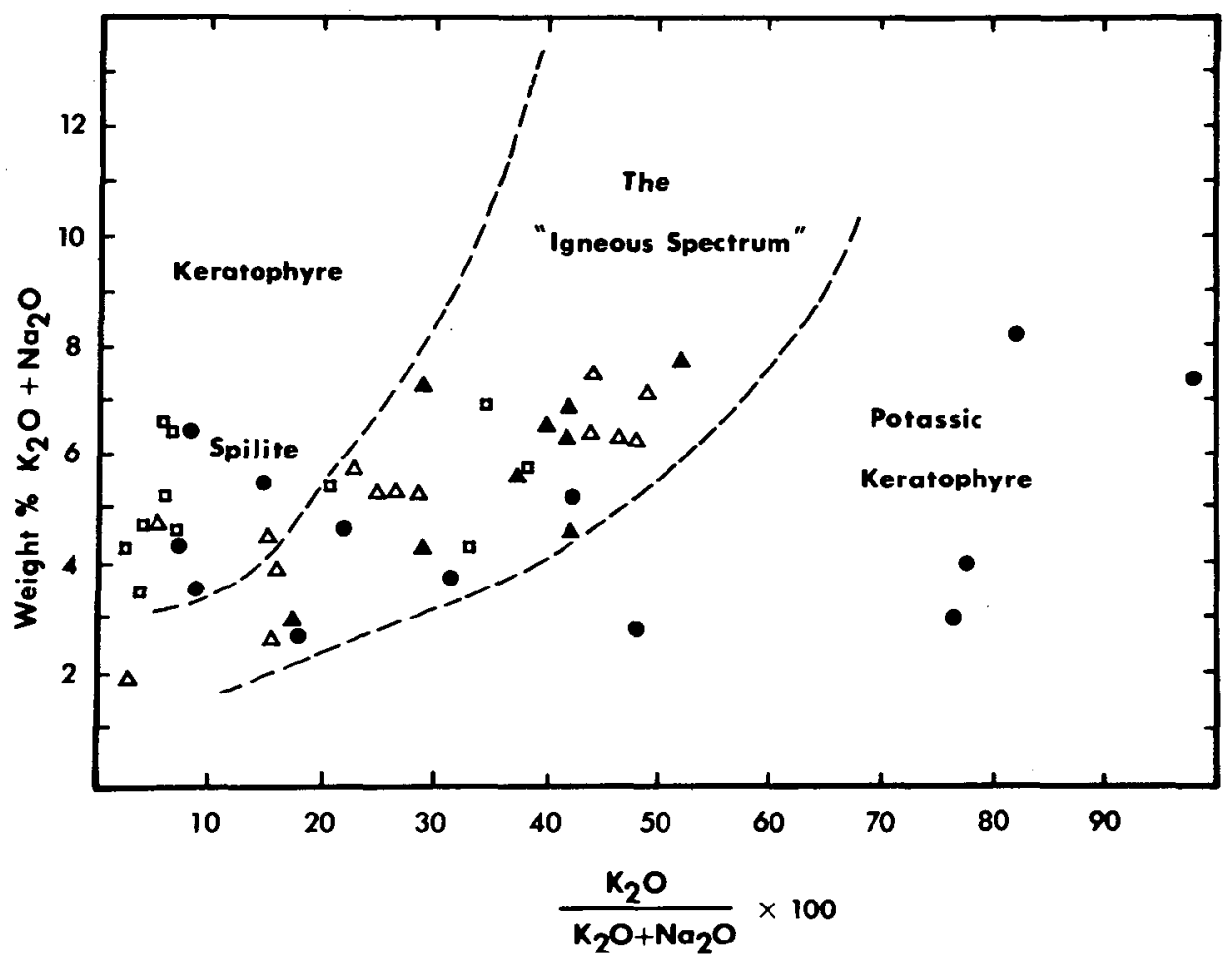

Fig. 9. Plot of alkali parameters (Hughes 1973b) of Fourchu valcanics, Coxheath volcanic and intrusive rocks, and Bourinot volcanics. Symbols as in Fig. 6. 
NW

Boisdale Peninsula

SE

Mira River Area
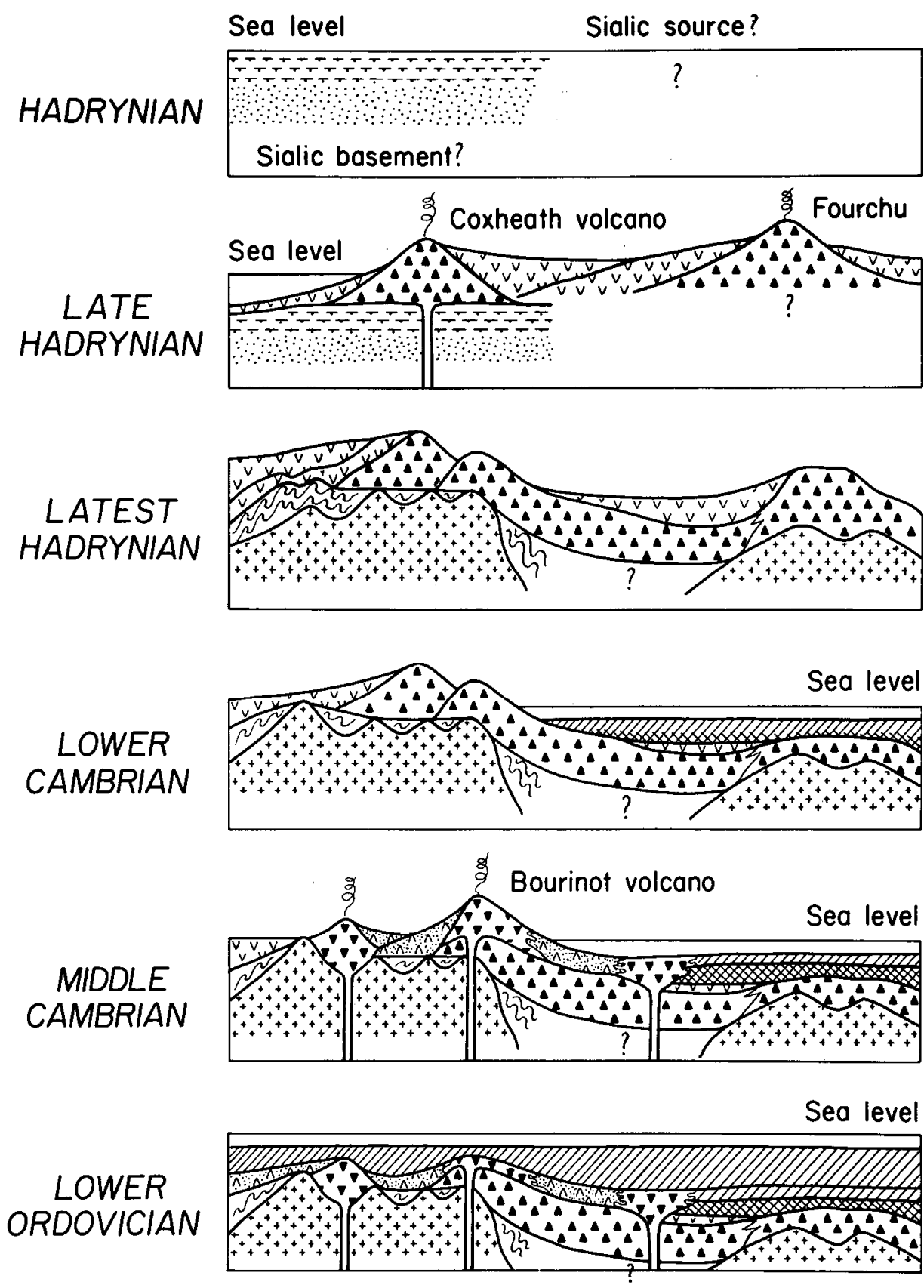

Fig. 10 Diagrams illustrating the tectonic development of southeastern Cape Breton Island from the Hadrynian to the Cambrian. Cambrian history is modified ofter Weeks (1954). For Legend see Fig. 2. 
Cape Breton Island is relatively clear, a controversy exists over the interpretation of approximately coeval volcanism on the Avalon Peninsula in southeastern Newfoundland. Papezik (1970) considered these rocks weakly alkaline and indicative of a period of block faulting of a Late Precambrian continental platform. Hughes (1970) and Hughes and Bruckner (1971), on the other hand, interpreted these rocks as calc-alkaline suites suggestive of a former volcanic island environment. Hughes (1973a) defended his interpretation on the grounds that the Late Precambrian volcanics of the Avalon Peninsula are spilites and keratophyres which have undergone low-grade allochemical metamorphism. Using a plot of alkali parameters (see also Hughes, 1973b) he demonstrated that many of the Avalon rocks in fact cannot represent compositions of primary igneous rocks and thus, that the weak alkaline affinities are a consequence of metasomatism. A plot of Hughes' alkali parameters for the rocks of southeastern Cape Breton Island (Fig. 9) shows that also several of our samples plot outside the "igneous spectrum". Post-magmatic low-grade metamorphic effects recognized in some thin sections may have been allochemical and can account for small changes in bulk composition. As in Newfoundland (Hughes, 1973a), most of the intrusive rocks of southeastern Cape Breton Island plot along a straight line within the igneous spectrum and therefore are least likely to have undergone post-magmatic metasomatic changes. The greatest likelihood of metasomatic changes exists in the volcanic rocks of the Bourinot Group, most of which are submarine. However, a net increase in total alkalis probably did not take place, because on the whole this group plots still well within the calc-alkaline field (Fig. 7). Adding the fact that like in the Hadrynian igneous suites intermediate rock types predominate volumetrically also in the Bourinot Group, we conclude that the salc-alkaline affinity of this group is primary.

\section{4) Timing of Post-Cambrian to Pre-Carboniferous} Deformation

Although the deformation of the Cambrian and Lower Ordovician rocks of southeastern Cape Breton Island is generally attributed to the Acadian orogeny (Weeks, 1954; Poole et al, 1970; Williams et al, 1972) it is interesting to re-examine the evidence for an Acadian orogeny in southeastern Cape Breton Island. Igneous, metamorphic, and structural events are summarized on Table 1 .

In the Boisdale area the youngest strata involved in penetrative deformation are Lower Ordovician slates of the McLeod Brook formation. The oldest rocks without this penetrative fabric in the Boisdale area belong to the McAdam Lake Formation which is of late Lower Devonian to early Middle Devonian age (D.C. McGregor, peraonal communication, 1971). This formation contains pebbles of deformed Cambrian rocks and is overlain disconformably or with slight angular unconformity by the Lower Carboniferous Grantmire Formation. Both the McAdam Lake and Grantmire formations are cut by Carboniferous and post-Carboniferous faults. Post-Cambrian granitic intrusions have not yet been positively identified on the Boisdale Peninsula, though local hornfelsing of Cambrian strata can be seen at Spruce Brook (Hutchinson, 1952; Helmstaedt and Tella, 1972).

In the Mira area Upper Cambrian rocks are the youngest penetratively deformed rocks. They are unconformably overlain by the Middle River Group which lacks a penetrative fabric and is generally flat lying and strongly tilted only in the vicinity of faults. The Middle River Group is of Silurian or Silurian to Lower Devonian age (Weeks, 1954). Two granite stocks in the Mira area yielded biotitewhole rock $\mathrm{Rb}-\mathrm{Sr}$ ages of 369 and $350 \pm 25 \mathrm{my}$ (Cormier, 1972). One of these, the Gillis Mountain stock, shows intrusive relationships with Cambrian rocks and is therefore definitely younger than the larger Lake Hadrynian intrusions. However, as indicated by Cormier (1972) the single-sample wholerock biotite-age determinations cannot yet be taken as proof for an Acadian age of the intrusions, especially since an updating of biotites in earlier intrusions of northern Cape Breton Island has been suspected. In spite of some possible Devonian plutonism, at present there is no basis for assuming that southeastern Cape Breton Island has been affected by penetrative deformation during the time that is normally allotted to the Acadian orogeny namely the mid-Devonian. If the Middle River Group is indeed of Silurian age, the deformation of the Cambrian rocks in the Mira area can only be bracketed between Late Cambrian and Silurian. In the Boisdale area pre-Carboniferous deformation must have occurred between the Lower Ordovician and the Late Lower Devonian, but also earlier than the mid-Devonian, the age normally assigned to the Acadian orogeny. Considering that the Bousinot volcanism occurred in a compressive tectonic environment, there may have been penetrative deformation in the Middle Cambrian, though this can at present not be separated from the postCambrian deformation.

\section{Discussion}

The tectonic history discussed here and summarized in Table 1 differs from that outlined by wiebe (1972) for northeastern Cape Breton Island. However, taking into account the difficulties encountered by Wiebe in bracketing the age of the two folding episodes recognized by him, some of these differences may be more apparent than real. It appears to be established that also in northeastern Cape Breton Island the deformation of the George River Group predates the oldest of the Hadrynian intrusions. Because there is no direct evidence for Wiebe's correlation of the George River Group with the Grenville Group, the age of the George River folding may not differ significantly from that in southeastern Cape Breton Island. Parallels between northeastern and southeastern Cape Breton Island are the ages and the calcalkaline character of the Late Hadrynian intrusions (Wiebe, 1972; Cormier, 1972) and the early (pre"Acadian") age of the second major folding period. Evidence for some younger intrusive activity (possibly Devonian) exists in both areas. Considering our present, still very incomplete knowledge of the tectonic history of Cape Breton Island as well as the uncertainties concerning the age of the George River Group, there is no justification to divide cape Breton into two distinct tectonic zones as proposed by Williams et al (1972) on the 
basis of a southwestward extension of a tectonic zonation established for Newfoundland.

Some questions concerning the tectonic history of the Avalon belt as a whole can be answered for southeastern Cape Breton Island and implications for other parts of the Avalon belt will be discussed.

The George River Group definitely represents the basement of the Late Hadrynian volcanic sequence. It was deformed and affected by a low-grade regional metamorphism prior to the emplacement of the Late Hadrynian intrusions, but the intense metamorphic recrystallization (Milligan, 1970) is a consequence of the thermal event related to these intrusions. The intense metamorphic recrystallization by itself cannot be taken as evidence for intence deformation (Williams et al, 1972). If the andesitic fragments in the George River limestone breccia on Long Island indeed indicate the beginning of the Coxheath volcanism during the time of deposition of the George River Group, a correlation of the George River Group with the Grenville Group is untenable. A nearby sialic source of possible pre-Hadrynian age is required to yield the quartz sands in the George River Group. The Hadrynian to Cambrian development of the area is summarized in Figure 10.

The composition of the Late Hadrynian volcanic and intrusive rocks is strongly suggestive that southeastern Cape Breton Island was part of a Hadrynian island arc. The association of andesitic to rhyolitic volcanics and granitoid intrusions with areas of low-pressure, high-temperature metamorphism is typical of low-pressure metamorphic belts. Such belts may occur either singly or paired with high-pressure metamorphic belts (Miyashiro, 1973). In either case the low-pressure belts are thought to represent zones of ancient volcanic chains on island arcs or continental margins with their underlying metamorphic complexes. The interpretation of southeastern Cape Breton Island as part of a formex island arc is consistent with a similar interpretation of the Hadrynian volcanics of the Avalon Peninsula of Newfoundland by Hughes (1970) and Hughes and Brtickner (1971). Hughes (1970) considered the formation of the volcanic islands of the Avalon Peninsula as a manifestation of the Avalonian orogeny originally proposed by Lilly (1966).

An alternative interpretation of the Avalon volcanics by Papezik $(1970 ; 1972)$ is based on the weakly alkalic character of the volcanics from which he concluded that these rocks are related to a period of tensional block faulting on a continental platform. Hughes (1973a) suggested that the mild alkalic affinity of the Avalon volcanics may be a consequence of metasomatic changes during lowgrade metamorphic processes. This difference of interpretation of the Avalon volcanics will have to be solved by further work. Arguments that the occurrence of detrital garnet and muscovite in Hadrynian sediments of the Avalon Peninsula is not consistent with the hypothesis of a former island arc complex but indicate an earlier Precambrian gneissic and granitic basement (Papezik, 1973). lose their strength considering that the island arc could have developed on a sialic basement. In addition, some of the Late Hadrynian intrusions in Cape Breton Island contain garnets near contacts with metasedimentary rocks. Garnets have also formed in the pelitic rocks of the George River Group. The possibility of the formation of garnets in low-pressure belts has recently been pointed out by Miyashiro (1973). A significantly older basement is therefore not required to explain the detrital garnets, and their occurrence is not inconsistent with an island-arc interpretation of the Avalon Peninsula.

If the Avalon peninsula indeed represents an extension of the island axc of Cape Breton Island, the lack of an equivalent of the George River Group with compression features resulting from the Avalonian orogeny and the relatively small outcrop area of the high-level holyrood granite on the Avalon peninsula can be explained by less intense uplift in Newfoundland and therefore a higher erosion level prior to the deposition of the Cambrian.

An island-arc intexpretation of the Hadrynian to Early Paleozoic tectonic history supports the model of a Late Hadrynian subduction zone under Cape Breton Island proposed by Dewey (1969) (see also Wiebe, 1972). Although there is as yet no evidence in Cape Breton Is land to establish the polarity of possible Hadrynian subduction, it has been assumed that Cape Breton was situated on the southeast side of Wilson's (1966) proto-Atlantic ocean, and oceanic crust was subducted southeastward beneath Cape Breton Island. According to Mitchell and Reading (1971), who discuss Bird and Dewey's (1970) plate-tectonic model of the Appalachians, a possible extension of a Late Precambrian Avalon peninsula island arc on the other side of the present Atlantic could be found in Wales where Late Precambrian to Early Cambrian volcanic activity of island-arc character is well documented. Just northwest of Snowdonia, in Anglesey (i.e. proto-Atlantic oceanwards from wales), Late Precambrian high-pressure, lowtemperature metamorphism has been reported by Shackleton (1969). It is possible that here a short segment of a former paired metamorphic belt is preserved (see also Thorpe, 1972, 1972a). An island-arc hypothesis of the Avalon belt (Rodgers, 1972) as a whole implies a regional compressional environment and would be inconsistent with Schenk's (1971, 1972) view that this belt represents a series of microcontinents that rifted away from Africa during the Hadrynian.

Our work in southeastern Cape Breton Island is consistent with Poole's (1967) and Rodgers' (1972) interpretation of the Avalon belt as a zone characterized by a similar Late Precambrian to Cambrian tectonic history. As pointed out by Rodgers (1972) the distance between the Avalon belt and the basement anticlinoria along the northwestern margin of the Appalachians decreases from about $300 \mathrm{~km}$ in Newfoundland to less than $40 \mathrm{~km}$ in the central Appalachians. In the same direction one can notice in the Avalon belt an increase of Paleozoic deformation which already in southern New Brunswick obliterates much of the original characteristics of the Avalonian island arc. This Paleozoic deformation is generally ascribed to the Middle Devonian Acadian orogeny 
which, according to the models of Wilson (1966) and Bird and Dewey (1970), resulted from a collision of two continental plates following the closing of a proto-Atlantic ocean. Based on the collision model, Naylor (1971) described the Acadian orogeny as a brief and abrupt event. Noticing the relatively early age of the "Acadian orogeny" in Cape Breton Island Wiebe (1972) concluded that the age of such collision would vary depending upon the shape of the converging continents. Whereas the Avalonian chain and the basement anticlinoria of the northwestern margin of the central Appalachians have collided directly during the Middle Devonian Acadian orogeny, other Paleozoic island arcs and ocean-floor sediments were telescoped between the two margins in the northern Appalachians, and record the Middle Devonian Acadian orogeny. If Middle Devonian deformation in the central northern Appalachians is the result of continental collision, it is difficult to conceive how the earlier "Acadian orogeny" in Cape Breton Island on the southeastern margin of this belt can be caused by the same collision. The pre-Middle Devonian penetrative deformation of Cape Breton Island may be part of the same general process leading to eventual continental collision but certainly should not be correlated with the Middle Devonian Acadian orogeny in the central parts of the Appalachian belt.

\section{Acknowledgements}

The fieldwork for this project was conducted in 1971 when the writers were employed by the Geological Survey of Canada. P. Desrosiers and N. Godbout were able field assistants. S. Courville and T.N. Irvine of the Geological survey of Canada respectively supervised the chemical analyses and helped in the computer processing of the results. R.F. Cormier of Saint Francis Xavier University dated several samples of granitic rocks and reported the results in 1972 . W.H. Poole visited in the field, provided much needed discussion, and critically read an early version of the manuscript. Special thanks are due to H.R. Oldale, Sydney River, Nova Scotia, for his hospitality and for introducing us to the geology of the Coxheath Hills.

\section{References}

BELL, W.A. and GORANSON, E.A., 1938, Sydney sheet (west half). Geol. Surv. Can., Map 360A.

BIRD, J.M. and DEWEY, J.F., 1970, Lithosphere plate continental margin tectonics and the evolution of the Appalachian orogen. Geol. Soc. Am. Bull., 81, pp. 1031-1059.

CORMIER, R.F., 1972, Radiometric ages of granitic rocks, Cape Breton Island, Nova Scotia. Can. J. Earth Sci., vol. 9, pp. 1074-1086.

DEWEY, J.F., 1969, Evolution of the Appalachian/ Caledonian orogen. Nature 222, pp. 124-128.

FAIRBAIRN, H.W., HURLEY, P.M., PINSON, W.H., and CORMIER, R.F., 1960, Age of the granitic rocks of Nova Scotia. Geol. Soc. Am. Bull., 71, pp. 399-414.
HELMSTAEDT, H. and TELLA, S., 1972, Structural history of pre-Carboniferous rocks in parts of eastern Cape Breton Island. Geol. Surv. Can., Paper 72-1, pp. 7-10.

HUGHES, C.J., 1970, The Late Precambrian Avalonian orogeny in Avalon, southeast Newfoundland. Am. J. Sci., 269, pp. 183-190.

1973a, Late Precambrian volcanic rocks of Avalon, Newfoundland - a spilite/ keratophyre province: recognition and implications. Can. J. Earth Sci., 10, pp. $272-282$.

, 1973b, Spilites, keratophyres, and the igneous spectrum. Geol. Mag., vol. 109, pp. 513-527.

, and BRÜCKNER, W.D., 1971, Late Precambrian rocks of eastern Avalon Peninsula, Newfoundland - a volcanic island complex. Can. J. Earth Sci., vol. 8, pp. 899-915.

HUTCHINSON, R.D., 1952, The stratigraphy and trilobite faunas of the Cambrian sedimentary rocks of Cape Breton Island, Nova Scotia. Geol. Surv. Can., Mem. 263, pp. 124.

IRVINE, T.N. and BARAGAR, W.R.A., 1971, A guide to the chemical classification of the common volcanic rocks. Can. J. Earth Sci., pp. 523548 .

KELLEY, D.G., 1967, Baddeck and Whycocomagh mapareas. Geol. Surv. Can., Mem. 351, pp. 65.

LILLY, H.D., 1966, Late Precambrian and Appalachian tectonics in the light of submarine exploration of the Great Bank of Newfoundland and in the Gulf of St. Lawrence, Preliminary views. Am. J. Sci., 264, pp. 569-574.

LIPMAN, P.W., 1970, Relations between Cenozoic andesitic and rhyolitic volcanism, western interior United States. Proc. Geol. Soc. Lond., 1662, pp. 36-39.

MARTIN, R.F. and PIWINSKI, A.J., 1972, Magmatism and tectonic settings. J. Geophys. Res., 77, pp. 4966-4975.

METZ, K., 1957, Lehrbuch der tektonischen Geologie. Enk-Verlag, Stuttgart, pp. 294.

MILLIGAN, G.C., 1970, Geology of the George River Series, Cape Breton - stratigraphy, structure and economic geology. Nova Scotia Dept. Mines Mem., vol. 7.

MITCHELL, A.M. and READING. M.G., 1971, Evolution of island arcs. Jour. Geology 79, pp. 253284 .

MIYASHIRO, A., 1973, Paired and unpaired metamorphic belts. Tectono-physics 17, pp. 241254 .

NAYLOR, R.S., 1971, Acadian orogeny : an abrupt and brief event. Science 172, pp. 558-560. 
PEACOCK, M.A., 1931, Classification of igneous rock series. J. Geol. 39, pp. 54-67.

PAPEZIK, V.S., 1970, Petrochemistry of volcanic rocks of the Harbour Main Group, Avalon Peninsula, Newfoundland. Can. J. Earth Sci., vol. 7., pp. 1485-1498.

1972, Late Precambrian ignimbrites in eastern Newfoundland and their tectonic significance. Proceed. 24th Int. Geol. Congr., Montreal, Quebec, Section 1, pp. 147-152.

1973, Detrital Garnet and Muscovite in Late Precambrian sandstone near St. John's, Newfoundland, and their significance. Can. J. Earth Sci., vol. 10, pp. 430-432.

POOLE, W.H., 1967, Tectonic evolution of Appalachian region of Canada; In: Geology of the Atlantic region. Roy. Soc. Can., Spec. Paper 4, pp. 951.

, SANFORD, B.V., WILLIAMS, H., and KELLEY, D.G., 1970, Geology of southeastern Canada. In: Geology and economic minerals of Canada. Geol. Surv. Can., Econ. Geol., Rep. 1, pp. 228-306.

RODGERS, J., 1972, Latest Precambrian (Post-Grenville) rocks of the Appalachian region. Am. J. Sci. 272 , pp. 507-520.

SCHENK, P.E., 1971, Southeastern Atlantic Canada, northwestern Africa, and continental drift. Can. J. Earth Sci., vol. 8, pp. 1218-1251.

- 1972, Eastern Canada as successive remnants of northwestern Africa. 24th Int. Geol. Congr., Sect. 6 , pp. 14-23.
SHACKLETON, R.M., 1969, The Precambrian and Lower Paleozoic rocks of wales, 1, University wales Press, Cardiff.

THORPE, R.S., 1972, Ocean floor basalt affinity of Precambrian glaucophane schist from Anglesey. Nature Physical Science 240, pp. 164-166.

- 1972a, Possible subduction zone origin for two Precambrian calc-alkaline plutonic complexes from southern Britain. Geol. Soc. Am. Bull. 83, pp. 3663-3668.

WANLESS, R.K., Compil., 1969, Isotopic age map of Canada. Geol. Surv. Can., Map 1256A.

, STEVENS, R.D., LACHANCE, G.R., and EDMONDS, C.M., 1968, Age determinations and geological studies. Geol. Surv. Can., Paper 67-2, Part A., pp. 127-131.

WEEKS, I.J., 1954, Southeast Cape Breton Island, Nova Scotia. Geol. Surv. Can., Mem, 277, pp. 112 .

WIEBE, R.A., 1972, Igneous and tectonic events in northeastern Cape Breton Island, Nova Scotia. Can. J. Earth Sci., vol. 9, pp. 1262-1277.

WILLIAMS, H., KENNEDY, M.J., and NEALE, E.R.W., 1972, The Appalachian structural province. In: Price, R.A. and Douglas, R.J.W. Variations in tectonic styles in Canada. Geol. Assoc. Can., Spec. Paper 11, pp. 181-261.

WILSON, J.T., 1966, Did the Atlantic close and then re-open? Nature 211, pp. 676-681. 